Document downloaded from:

http://hdl.handle.net/10251/61607

This paper must be cited as:

Álvarez, R.; del Hoyo, A.; García Breijo, FJ.; Reig Armiñana, J.; Del Campo, E.; Guera, A.; Barreno, E.; Casano, L. (2012). Different strategies to achieve Pb-tolerance by the two Trebouxia algae coexisting in the lichen Ramalina farinacea. Journal of Plant Physiology. 169(18):1797-1806. doi:10.1016/j.jplph.2012.07.005.

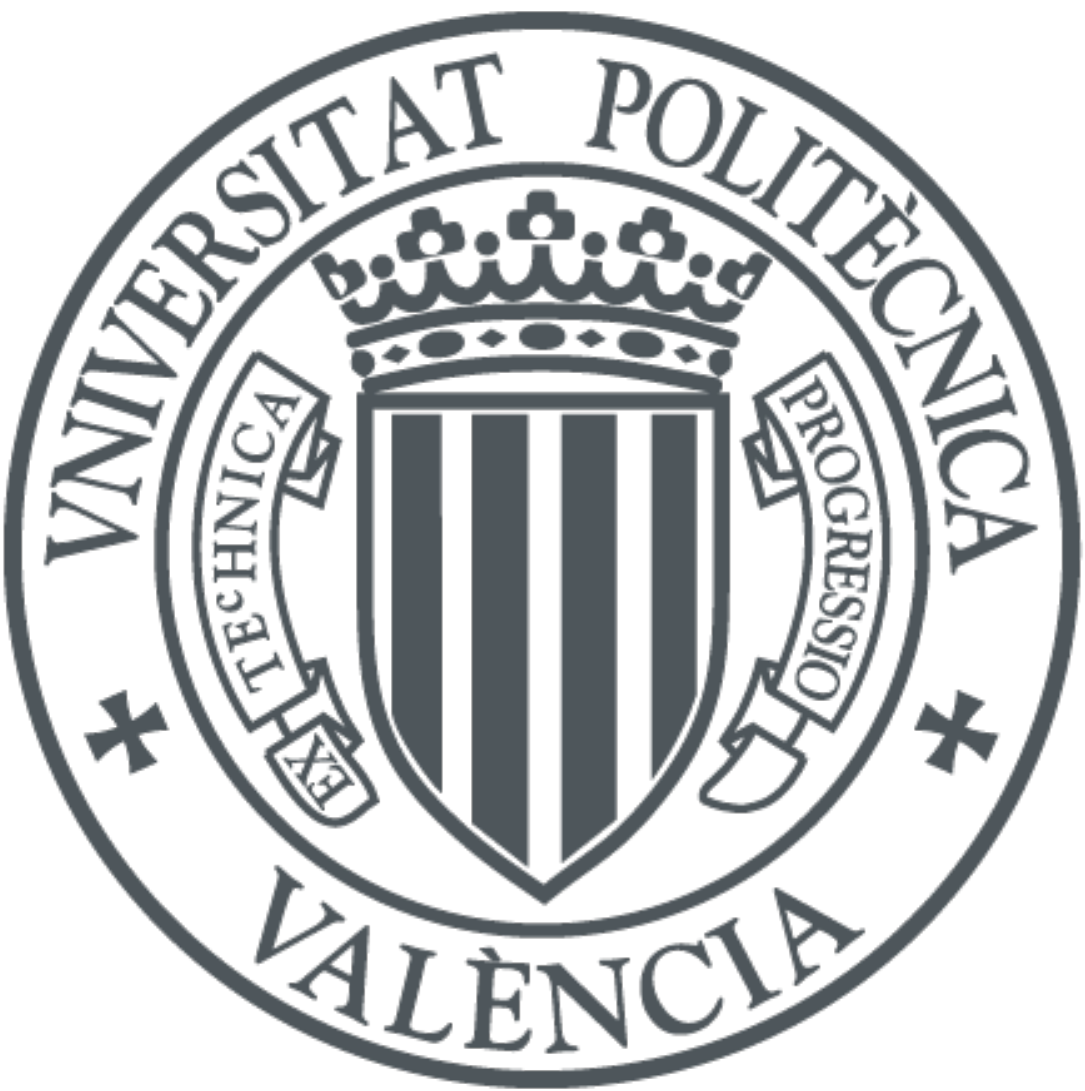

The final publication is available at

http://dx.doi.org/10.1016/j.jplph.2012.07.005

Copyright Elsevier

Additional Information 


\title{
Different strategies to achieve Pb-tolerance by the two Trebouxia algae coexisting in the lichen Ramalina farinacea
}

\author{
Raquel Álvarez ${ }^{\mathrm{a}}$, Alicia del Hoyo ${ }^{\mathrm{a}}$, Francisco García-Breijo ${ }^{\mathrm{b}, \mathrm{c}}$, José Reig-Armiñana ${ }^{\mathrm{b}}$, \\ Eva M. del Campo ${ }^{a}$, Alfredo Guéra ${ }^{\mathrm{a}}$, Eva Barreno ${ }^{\mathrm{b}}$, Leonardo M. Casano $^{\mathrm{a}, *}$ \\ a Departamento de Biología Vegetal, Universidad de Alcalá, 28871-Alcalá de Henares, Madrid, Spain \\ ${ }^{\mathrm{b}}$ Departamento de Botánica, Universitat de València, ICBIBE, Fac. C. Biológicas, c/Dr. Moliner 50, 46100-Burjassot, Valencia, Spain \\ c Departamento de Ecosistemas Agroforestales, Universidad Politécnica de Valencia, Camino de Vera s/n, 46020 Valencia, Spain
}

A R T I C L E I N F O

Keywords:

Heavy metal tolerance

Lead

Lichen microalgae

Stress response

Trebouxia algae

\begin{abstract}
A B S T R A C T
Lichen thalli are permeable to airborne substances, including heavy metals, which are harmful to cell metabolism. Ramalina farinacea shows a moderate tolerance to $\mathrm{Pb}$. This lichen comprises two Trebouxia phycobionts, provisionally referred to as TR1 and TR9, with distinct physiological responses to acute oxidative stress. Thus, there is a more severe decay in photosynthesis and photosynthetic pigments in TR1 than in TR9. Similarly, under oxidative stress, antioxidant enzymes and HSP70 protein decrease in TR1 but increase in TR9. Since Pb toxicity is associated with increased ROS formation, we hypothesized greater $\mathrm{Pb}$ tolerance in this phycobiont. Accordingly, the aim of the present study was to characterize the physiological differences in the responses of TR1 and TR9 to Pb exposure. Liquid cultures of isolated phycobionts were incubated for 7 days in the presence of $\mathrm{Pb}\left(\mathrm{NO}_{3}\right)_{2}$. Thereafter, extracellular and intracellular $\mathrm{Pb}$ accumulation, photosynthetic pigments, and photosynthesis (as modulated chlorophyll fluorescence) were analyzed along with the antioxidant enzymes glutathione reductase (GR), superoxide dismutase (SOD), ascorbate peroxidase (APx), and catalase (CAT), and the stress-related protein HSP70. $\mathrm{Pb}$ uptake increased with the amount of supplied $\mathrm{Pb}$ in both algae. However, while significantly more metal was immobilized extracellularly by TR9, the amount of intracellular Pb accumulation was three times higher in TR1. In neither of the phycobionts were significant effects on photosynthetic pigments or photosynthetic electron transport observed. While under control conditions GR, SOD, and APx levels were significantly higher in TR1 than in TR9, only in the latter were these enzymes induced by Pb. This resulted in quantitatively similar antioxidant activities in the two algae when exposed to $\mathrm{Pb}$. In conclusion, the phycobionts of $R$. farinacea make use of two different strategies against stress, in which the integration of distinct anatomical and physiological features affords similar levels of $\mathrm{Pb}$ tolerance.
\end{abstract}

\section{Introduction}

Lichen thalli can be considered as self-contained minibiospheres resulting from the close, symbiotic, morphological and physiological integration of a nutritionally specialized fungus (mycobiont) and at least a green alga and/or cyanobacteria (photobionts) (Margulis and Barreno, 2003; Casano et al., 2011). In many cases, lichenization allows both the photobiont and the mycobiont to thrive under extremely harsh environmental conditions, such as in the presence of high concentrations of heavy metals (HMs) and other environmental pollutants, where individually they would be

Abbreviations: APx, ascorbate peroxidase; CAT, catalase; EDXS, energy dispersive X-ray spectroscopy; GR, glutathione reductase; ROS, reactive oxygen species; SOD, superoxide dismutase; TEM, transmission electron microscopy.

* Corresponding author. Tel.: +34 91 8856432; fax: +34 918855066.

E-mail addresses: leonardo.casano@uah.es, leocasano@gmail.com (L.M. Casano). rare or non-viable (Garty, 2001; De Vera et al., 2008; Grube, 2010). Lichens do not develop either root-like structures or a waxy impermeable cuticle; consequently airborne substances, including HMs, accumulate within thalli in amounts that depend on the atmospheric concentration (Garty, 2001; Loppi and Frati, 2006). To cope with the potential metabolic disturbances caused by intracellular HM accumulation, lichen thalli have developed an armamentarium of biological responses. Indeed, there is vast diversity in HMtolerance among lichens, ranging from moderately tolerant species, e.g., Lecanora conizaeioides (Hauck et al., 2007) and Ramalina farinacea (Branquinho et al., 1997), to sensitive ones, e.g., Hypogymnia physodes and Pseudoevernia spp. (Hauck et al., 2007). Based on all of these features, lichens can be viewed as extremely valuable biomonitors of environmental pollution (Garty, 2001; Barreno, 2002; Nimis et al., 2002 and references therein).

The HM tolerance of lichens is an expanding area of research, as recently pointed out by several authors (Sanità di Toppi et al., 2008; Bačkor and Loppi, 2009; Pawlik-Skowronska and Bačkor, 
2011). However, the physiological basis of such tolerance, and especially whether the mycobiont and photobiont differ in their sensitivity to HMs, is still poorly understood and somewhat controversial. Trebouxia spp. algae were reported to be more sensitive to HMs and other pollutants than the corresponding mycobionts (Ahmadjian, 1993), thus conditioning the HM-sensitivity of the holobiont. However, Hauck and co-workers (2007), in their analysis of photobiont selectivity in epiphytic lichens with different HM sensitivities, found that the same trebouxioid microalgae may be present in HM-tolerant and HM-sensitive lichens. For instance, these authors noted that Trebouxia hypogymniae was the phycobiont of the HM-sensitive lichen $H$. physodes and of the HM-tolerant Lecidea silacea, suggesting that photobionts are not the key determinant of pollution sensitivity in the most common lichens (Hauck et al., 2007). Conversely, Branquinho et al. (1997), Beck (1999), Branquinho (2001), Bačkor and Vaczi (2002), and Bačkor et al. (2007) provided evidence from both field and "in vitro" studies indicating the involvement of photobionts in the HM-tolerance of lichen thalli. For instance, Branquinho et al. (1997) observed that the effects of $\mathrm{Pb}$ on four lichen species comprising different photobionts were dependent on the nature of the photobiont. As determined in measurements of PSII photochemical reactions, the cyanobiont lichen Peltigera canina was the most Pb-sensitive, consistent with its previously documented responses to other HMs (Brown and Beckett, 1985). Within chlorobiont lichens, those containing Trebouxia spp. as primary algae (Parmelia caperata or $R$. farinacea) were shown to be moderately Pb-tolerant, while the HMsensitivity of Lobaria pulmonaria, in which Dictyochloropsis is the primary phycobiont, is intermediate (Branquinho et al., 1997). The authors of these studies concluded that the observed effects of $\mathrm{Pb}$ on lichens are dependent only on the physiological response of the photobionts.

Exposure to HMs in general, and to $\mathrm{Pb}$ in particular, increases the production of reactive oxygen species (ROS), including superoxide radicals, hydroxyl radicals, and hydrogen peroxide, thereby unbalancing the cellular redox status (Verma and Dubey, 2003; Liu et al., 2008; Słomka et al., 2008; Phang et al., 2011). At high levels, or following acute increases of metal pollutants, algal cells are injured because the resulting ROS levels exceed the capacities of cellular antioxidant protection systems. ROS can react with cellular components (lipids, proteins, pigments, nucleic acids) to cause lipid peroxidation, membrane damage, and enzyme inactivation, thus affecting many physiological processes as well as cell viability (Pinto et al., 2003; del Hoyo et al., 2011 and references therein). One process highly sensitive to $\mathrm{Pb}$ is photosynthesis, probably due to the strong detrimental effects of ROS on critical components of the photosynthetic machinery (Calatayud et al., 1999). Sharma and Dubey (2005) reviewed the multiple impacts of $\mathrm{Pb}$ on the chloroplasts of vascular plants, including structural disorders of thylakoids, quantitative and qualitative alterations in the pigment composition, changes in lipid composition with consequent disruption of membrane permeability, and alterations of the photochemical activities of PSI, PSII, and the photosynthetic electron transport chain. In addition, $\mathrm{Pb}$ blocks photosynthesis by inhibiting the carboxylase activity of RuBisCO, and probably other enzymes of the Calvin cycle as well. Irreversible binding of $\mathrm{Pb}$ with the RuBisCO enzyme dissociates the latter into its component subunits, leading to a loss of activity. In other cases, Pb affects enzyme activities, often towards inhibitory effects, either directly, by interacting with - $\mathrm{SH}$ groups, or indirectly, via Pb-induced ROS, which in turn oxidizes the $-\mathrm{SH}$ groups of proteins (Liu et al., 2009).

The lichen $R$. farinacea has a world-wide distribution and is encountered in polluted and unpolluted areas (Riga-Karandinos and Karandinos, 1998; Arhoun et al., 2000; Loppi and Frati, 2006; Fadila et al., 2009), indicating a moderate tolerance to $\mathrm{Pb}$, as has also been suggested by laboratory experiments (Branquinho et al., 1997). In addition, in previous studies we determined that, regardless of the geographic location of this lichen, two genetically and morphologically different Trebouxia algae (provisionally named TR1 and TR9) coexist within every thallus (del Campo et al., 2010; Casano et al., 2011; del Hoyo et al., 2011). TR1 and TR9 show distinct physiological responses to the oxidative stress caused by the ROS propagator cumene hydroperoxide (del Hoyo et al., 2011). Thus, in TR1, there is a more severe decay in photosynthesis, a reduction in the non-photochemical dissipation of absorbed energy, and diminished amounts of photosynthetic pigments and proteins. Oxidative stress causes a decrease in antioxidant enzymes and HSP70 protein in TR1, but an increase in TR9. Based on these observations, we hypothesized that TR9 microalgae would be relatively more $\mathrm{Pb}$-tolerant than TR1, thus conditioning the Pb-tolerance of the holobiont. It should be noted that, to the best of our knowledge, the physiological response to HMs of different phycobionts coexisting within the same lichen thallus has yet to be analyzed.

Therefore, the aim of the present study was to determine the basis for the physiological differences between cultured TR1 and TR9 phycobionts in their response to $\mathrm{Pb}$ exposure. Isolated axenic cultures of TR1 and TR9 microalgae were exposed to nutrient solutions containing different concentrations of lead, and the subsequent effects on extracellular and intracellular Pb accumulation, photosynthetic pigment content, chlorophyll fluorescence, and quenching parameters were examined. In addition, the detoxification response to $\mathrm{Pb}$ was determined with respect to the levels of several important antioxidant enzymes, i.e., glutathione reductase (EC 1.6.4.2) (GR), superoxide dismutase (EC 1.15.1.1) (SOD), ascorbate peroxidase (EC 1.11.1.11)(APX), and catalase (EC 1.11.1.6) (CAT), and to the amount of the cellular stress-related protein HSP70.

\section{Materials and methods}

Phycobiont isolation and culture. Lead treatments. Intracellular lead uptake in Trebouxia TR1 and T. TR9 cells

Trebouxia TR1 and T. TR9 were isolated in our laboratories from a population of the lichen Ramalina farinacea (L.) Ach. following the method of Gasulla et al. (2010). Thalli were collected in the air-dried state on Quercus rotundifolia Lam. at $S^{a}$ El Toro (Castellón, Spain; $\left.39^{\circ} 54^{\prime} 16^{\prime \prime} \mathrm{N}, 0^{\circ} 48^{\prime} 22^{\prime \prime} \mathrm{W}\right)$. Samples were frozen at $-20^{\circ} \mathrm{C}$ for 3 months, at which time they were cultured in liquid or semisolid Bold 3N medium (Bold and Parker, 1962) in a growth chamber at $15^{\circ} \mathrm{C}$, under a 14 -h/10-h light/dark cycle (lighting conditions: $25 \mu \mathrm{mol} \mathrm{m}^{-2} \mathrm{~s}^{-1}$ ).

Three-week-old liquid cultures of TR1 and TR9 phycobionts (exponential growth phase) were diluted to $2 \times 10^{6}$ cells $/ \mathrm{ml}$ and incubated with 0,50 , or $100 \mu \mathrm{M} \mathrm{Pb}\left(\mathrm{NO}_{3}\right)_{2}$ dissolved in Bold $3 \mathrm{~N}$ culture medium. Typically, $50 \mathrm{ml}$ of treated cultures rendered ca. 250-300 mg of microalgae cells. After 7 days in a growth chamber at $15^{\circ} \mathrm{C}$, the algal suspensions were centrifuged and then rinsed once with $200 \mathrm{ml}$ of ultrapure cold water, after which extracellular $\mathrm{Pb}$ was eluted with $20 \mathrm{mM} \mathrm{Na}_{2}$-EDTA, pH 4.5, following the procedure described by Branquinho and Brown (1994) and Branquinho et al. (1997). Lead speciation of the 50 or $100 \mu \mathrm{M} \mathrm{Pb}\left(\mathrm{NO}_{3}\right)_{2}$ culture media was estimated by employing the computer program MINTEQ ver. 3.0 (http://www2.lwr.kth.se/English/OurSoftware/vminteq/) (Table 1). It should be noted that all chemical species formed by $\mathrm{Pb}$ in both treatments were aqueous soluble, and the sum of free active and EDTA-complexed $\mathrm{Pb}$ accounted for $>60 \%$ of such species. In vascular plants, EDTA maintains the solubility of $\mathrm{Pb}$, thus facilitating its absorption and translocation as Pb-EDTA complexes (Epstein et al., 1999). 
Table 1

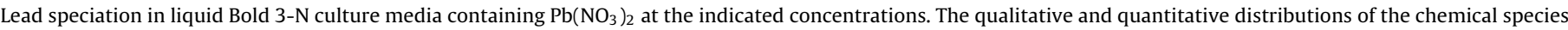
of $\mathrm{Pb}$, including solubility criteria, were estimated through the Visual MINTEQ chemical equilibrium model (MINTEQ ver. 3.0).

\begin{tabular}{|c|c|c|c|c|c|c|c|}
\hline $\begin{array}{l}\mathrm{Pb}\left(\mathrm{NO}_{3}\right)_{2} \\
\text { treatment }\end{array}$ & $\begin{array}{l}\text { Free } \mathrm{Pb}^{2+} \\
\text { concentra- } \\
\text { tion }\end{array}$ & $\begin{array}{l}\text { Free } \mathrm{Pb}^{2+} \\
\text { activity }\end{array}$ & $\begin{array}{l}\text { Total } \\
\text { soluble } \\
\text { forms (\%) }\end{array}$ & $\begin{array}{l}\text { Complexed } \\
\text { with EDTA }\end{array}$ & $\begin{array}{l}\text { Complexed } \\
\text { with } \mathrm{OH}^{-}\end{array}$ & $\begin{array}{l}\text { Complexed } \\
\text { with } \mathrm{PO}_{4}\end{array}$ & $\begin{array}{l}\text { Complexed } \\
\text { with } \mathrm{SO}_{4}\end{array}$ \\
\hline $50 \mu \mathrm{M}$ & $3.15 \mathrm{E}^{-5} \mathrm{M}$ & $2.13 \mathrm{E}^{-5} \mathrm{M}$ & 100 & $1.11 \mathrm{E}^{-5} \mathrm{M}$ & $1.88 \mathrm{E}^{-7} \mathrm{M}$ & $1.81 \mathrm{E}^{-6} \mathrm{M}$ & $2.21 \mathrm{E}^{-6} \mathrm{M}$ \\
\hline $100 \mu \mathrm{M}$ & $7.10 \mathrm{E}^{-5} \mathrm{M}$ & $4.79 \mathrm{E}^{-5} \mathrm{M}$ & 100 & $1.22 \mathrm{E}^{-5} \mathrm{M}$ & $4.23 \mathrm{E}^{-7} \mathrm{M}$ & $4.01 \mathrm{E}^{-6} \mathrm{M}$ & $4.94 \mathrm{E}^{-6} \mathrm{M}$ \\
\hline
\end{tabular}

Intracellular Pb uptake was assayed in cellular pellets after EDTA washings. Briefly, ca. $50 \mathrm{mg}$ of TR1 and TR9 cells were digestedmineralized by the addition of $4 \mathrm{ml}$ of $60 \% \mathrm{HNO}_{3}, 2 \mathrm{ml}$ of $30 \%$ $\mathrm{H}_{2} \mathrm{O}_{2}$, and $4 \mathrm{ml}$ of $\mathrm{H}_{2} \mathrm{O}$ followed by incubation at $200{ }^{\circ} \mathrm{C}$ for $10 \mathrm{~min}$. Digested samples were filtered (cellulose, $47 \mu \mathrm{m}$ ) and diluted to $25 \mathrm{ml}$ with $\mathrm{H}_{2} \mathrm{O}$. $\mathrm{Pb}$ content was analyzed by graphite furnace atomic absorption spectrometry (GFAAS). The lead content of the algal cells was determined in triplicate in two independent experiments.

\section{$\mathrm{X}$-ray microanalysis of $\mathrm{Pb}$ uptake}

The extracellular and intracellular distributions of Pb in TR1 and TR9 phycobionts were determined using transmission electron microscopy (TEM) coupled with energy dispersive X-ray spectroscopy (EDXS). The intensity of the lead signal was not enough to perform accurate absolute determinations of the metal in all trials. Therefore, we compared the intensity of the detected lead peaks with that of osmium, as a reference element, since all cells were post-fixed with osmium tetroxide $\left(\mathrm{OsO}_{4}\right)$. Osmium is tightly bound to lipids such that it is present in all biological membranes of post-fixed samples. Therefore, the relative abundance of $\mathrm{Pb}$ in each subcellular compartment was expressed as the ratio: $(\mathrm{Pb} / \mathrm{Pb}+\mathrm{Os}) 100$ (Table 3). Accordingly, liquid cultures of TR1 and TR9 were treated with 0 or $100 \mu \mathrm{M} \mathrm{Pb}\left(\mathrm{NO}_{3}\right)_{2}$ as described above. After 7 days of treatment, the algal suspensions were centrifuged and then rinsed twice with $50 \mathrm{mM} \mathrm{K-Pi,} \mathrm{pH} \mathrm{7.0,100} \mathrm{mM} \mathrm{NaCl}$, and $2.5 \mathrm{mM}$ EDTA, and twice with ultrapure cold water. This washing step removed loosely bound $\mathrm{Pb}$ while maintaining tightly bound $\mathrm{Pb}$ to the cell wall. Thereafter, the cells were equilibrated in liquid Bold $3 \mathrm{~N}$ medium and fixed with $4 \%$ glutaraldehyde in the same medium. After $2 \mathrm{~h}$ at $4{ }^{\circ} \mathrm{C}$, the samples were washed in $0.01 \mathrm{M}$ PBS buffer, $\mathrm{pH}$ 7.4, post-fixed with $1 \% \mathrm{OsO}_{4}$ in $0.01 \mathrm{M} \mathrm{PBS}, \mathrm{pH} 7.4\left(2 \mathrm{~h}\right.$ at $4{ }^{\circ} \mathrm{C}$ ), gently centrifuged, and washed again. They were then dehydrated at room temperature in a graded series of ethanol, starting at 50\% and increasing to $70 \%, 95 \%$, and $100 \%$ for no less than $20-30 \mathrm{~min}$ for each step. The fixed and dehydrated samples were embedded in Spurr's resin according to the manufacturer's instructions (EMS, Electron Microscopy Sciences). For TEM-EDXS analysis, 90-nm sections were cut with a diamond knife (DIATOME Ultra $45^{\circ}$ ) using an Ultramicrotome (Ultratome Nova LKB Bromma), and mounted on 100 mesh carbon-coated copper grids. The prepared sections were observed with a Tecnai $\mathrm{G}^{2}$ F20 field emission gun transmission electron microscope coupled to EDXS, under an acceleration voltage of $200 \mathrm{kV}$. The system was equipped with a CCD GATAN digital camera and the software acquisition and image processing package "Digital Micrograph ${ }^{\mathrm{TM}}$ ". Imaging was carried out at the SCSIE service of the University of Valencia.

\section{Analysis of antioxidant enzymes activities and HSP70}

Cells of TR1 and TR9 microalgae (ca. 200-250 mg) were homogenized using a mortar and pestle in the presence of a minimal amount of siliceous particles and $0.5 \mathrm{ml}$ of grinding medium, containing $50 \mathrm{mM}$ Tris-Cl, pH 7.5, $2 \mathrm{mM}$ EDTA, $1 \mathrm{mM}$ ascorbic acid, $10 \%(\mathrm{v} / \mathrm{v})$ glycerol, and $1 \%(\mathrm{w} / \mathrm{v})$ insoluble polyvinyl pyrrolidone
(PVPP). The homogenates were centrifuged for $2 \mathrm{~min}$ at $200 \times g$ to remove the siliceous particles, PVPP, unbroken cells and cell-wall debris. Supernatants were centrifuged at $20,000 \times g$ for $20 \mathrm{~min}$. All of these steps were performed at $4{ }^{\circ} \mathrm{C}$. Antioxidant enzyme activity assays and the immunodetection of HSP70 were carried out using the 20,000 $\times g$-supernatant in spectrophotometric and zymogram analyses. SOD activity was determined spectrophotometrically at $560 \mathrm{~nm}$; GR activity was assayed at $25^{\circ} \mathrm{C}$ based on the decrease in $A_{340}$ due to NADPH oxidation, as previously reported (del Hoyo et al., 2011). CAT and APx activities were measured according to the procedures described by Aebi (1984) and Amako et al. (1994), respectively. All determinations were in triplicate.

For zymograms, soluble proteins (usually 10 or $20 \mu \mathrm{g}$ ) were separated electrophoretically by native PAGE (ND-PAGE). GR and SOD activities were developed as described (del Hoyo et al., 2011). HSP70 protein was immunoassayed by protein blot. Briefly, after SDS-PAGE, the separated proteins were transferred to PVDF membranes (Millipore, Billerica, MA, USA). Immunocomplexes with commercially available antibodies against HSP70 (Agrisera, Vännäs, Sweden) were detected with an alkaline phosphatase protein blotting system (Sigma-Aldrich Co., St. Louis, MO, USA).

\section{Determination of photosynthetic pigments}

TR1 and TR9 phycobiont cells (ca. $10 \mathrm{mg}$ ) were re-suspended in $1 \mathrm{ml}$ of $100 \%$ dimethyl sulfoxide and incubated for $15 \mathrm{~min}$ at $65^{\circ} \mathrm{C}$. This treatment solubilized at least $98 \%$ of the photosynthetic pigments (data not shown). The samples were centrifuged at $5000 \times g$ for $5 \mathrm{~min}$, after which chlorophyll $a$, chlorophyll $b$, and total carotenoids were measured spectrophotometrically according to Wellburn (1994). In other experiments, the components of the xanthophyll cycle, i.e., violaxanthin, antheraxanthin, and zeaxanthin, were measured in DMSO extracts by HPLC, as described in Gasulla et al. (2009). All determinations were made in duplicate.

\section{Measurements of chlorophyll a fluorescence}

Chlorophyll $a$ fluorescence was measured at room temperature using a pulse modulation fluorometer (PAM-2000, Walz, Effeltrich, Germany). After the washings, control and treated TR1 and TR9 suspensions (approximately $100 \mathrm{mg}$ cell) were filtered through cellulose acetate discs under slight vacuum in order to collect cells on a solid support, facilitating fluorescence measurements. Thereafter, the cells were maintained in a fully hydrated state by layering the discs on filter paper moistened with distilled water, and kept in the dark for 15 min prior to chlorophyll $a$ fluorescence measurements. The minimal fluorescence yield $\left(F_{0}\right)$ was obtained by illumination of the phycobionts with a weak measuring beam from a light-emitting diode. A saturating pulse $(600 \mathrm{~ms})$ of white light (at a photosynthetic photon fluence rate of $4000 \mu \mathrm{mol} \mathrm{m}^{-2} \mathrm{~s}^{-1}$ over the waveband $400-700 \mathrm{~nm}$ ), closing all reaction centers, was applied to obtain the maximal fluorescence $\left(F_{\mathrm{m}}\right)$. Variable fluorescence in dark-adapted samples $\left(F_{\mathrm{v}}\right)$ was calculated as $F_{\mathrm{m}}-F_{\mathrm{o}}$. Following 2 min of dark re-adaptation, actinic white light ( $40 \mu \mathrm{mol}$ photons $\left.\mathrm{m}^{-2} \mathrm{~s}^{-1}\right)$ was switched on, and 
Table 2

Intracellular lead content in Trebouxia TR1 and T. TR9 phycobionts exposed to $\mathrm{Pb}\left(\mathrm{NO}_{3}\right)_{2}$.

\begin{tabular}{lcl}
\hline Phycobiont & $\mathrm{Pb}\left(\mathrm{NO}_{3}\right)_{2}$ treatment $(\mu \mathrm{M})$ & Pb content $(\mu \mathrm{g} / \mathrm{g} \mathrm{DW})$ \\
\hline TR1 & 0 & $0.35( \pm 0.06) \mathrm{a}$ \\
TR1 & 50 & $10.6( \pm 0.50) \mathrm{b}^{* *}$ \\
TR1 & 100 & $68.3( \pm 8.02) \mathrm{c}^{* *}$ \\
TR9 & 0 & nd $(A)$ \\
TR9 & 50 & $3.21( \pm 0.02) \mathrm{B}^{* *}$ \\
TR9 & 100 & $21.05( \pm 0.20) \mathrm{C}^{* *}$ \\
\hline
\end{tabular}

The results are expressed as means ( \pm standard deviation, $n=3$ ); nd: not detected. The values denoted by different lower-case or capital letters indicate significant differences among $\mathrm{Pb}\left(\mathrm{NO}_{3}\right)_{2}$ treatments for TR1 and TR9, respectively, when subjected to a one-way ANOVA (in which the lead concentration served as the factor) and Student's $t$ test $(P<0.05){ }^{* *}$ indicates highly statistically significant difference $(P<0.01)$ between TR1 and TR9 for each $\mathrm{Pb}\left(\mathrm{NO}_{3}\right)_{2}$ treatment.

600-ms saturating pulses were applied at 60-s intervals to determine: the maximum fluorescence yield during actinic illumination $\left(F_{\mathrm{m}}^{\prime}\right)$; the level of modulated fluorescence during a brief interruption of actinic illumination in the presence of far-red light $\left(F_{0}^{\prime}\right)$; and the chlorophyll fluorescence yield during actinic illumination $\left(F_{\mathrm{S}}\right)$. Quenching as a result of non-photochemical dissipation of absorbed light energy $\left(q_{\mathrm{N}}\right)$ was determined at each saturating pulse according to the equation $q_{\mathrm{N}}=1-\left(F_{\mathrm{m}}^{\prime}-F_{\mathrm{o}}^{\prime}\right) /\left(F_{\mathrm{m}}-F_{\mathrm{o}}\right.$ ) (Bilger and Björkman, 1991). The quantum efficiency of PSII photochemistry, $\Phi_{\text {PSII }}$, which is closely associated with the quantum yield of noncyclic electron transport, was estimated from $\left(F_{\mathrm{m}}^{\prime}-F_{\mathrm{s}}\right) / F_{\mathrm{m}}^{\prime}$ (Genty et al., 1989).

\section{Statistics}

Every experiment was repeated between two and nine times, starting from new stock material and freshly prepared, new cultures. The data were statistically analyzed using a one-way analysis of variance, in which either the $\mathrm{Pb}\left(\mathrm{NO}_{3}\right)_{2}$ concentration or the algal species served as the factor. When appropriate, differences among treatment means were evaluated using Student's $t$ test.

\section{Results}

\section{Quantitative and microscopic analyses of extra- and intracellular} $\mathrm{Pb}$ accumulation

After 7 days of $\mathrm{Pb}$ treatment, metal bound to cell walls (extracellular $\mathrm{Pb}$ ) was eluted through washings with $20 \mathrm{mM}$ EDTA ( $\mathrm{pH}$ 4.5), and the intracellular $\mathrm{Pb}$ accumulation was then determined. As expected, $\mathrm{Pb}$ uptake by both Trebouxia taxa (TR1 and TR9) increased with increasing amounts of supplied $\mathrm{Pb}$ (Table 2). However, despite the same $\mathrm{Pb}$ treatment, metal concentrations in TR1 cells were approximately three times higher than those in TR9 cells. Compartmentalization and complexation of HMs at a subcellular level play important roles in HM detoxification by plant tissues. Accordingly, we searched for possible differences in the extra- and intracellular distribution of Pb between TR1 and TR9 algae, subjecting the cells to TEM-coupled EDXS. In these experiments, the washings, described in materials and methods, were less stringent than those employed in quantitative intracellular lead determinations, in order to avoid losses of cell wall-bound metal. The semi-quantitative data provided by TEM-EDXS microanalysis confirmed the quantitative determinations of $\mathrm{Pb}$ uptake, since the sum of the accumulated $\mathrm{Pb}$ in the two intracellular fractions (cytosol-chloroplast + vesicles) was significantly higher in TR1 than in TR9 (Table 3). Interestingly, the ultrastructural analysis showed different patterns of electro-dense deposits of $\mathrm{Pb}$ in the cell walls, cytoplasm, and vesicles of TR1 and TR9 algae (Fig. 1 and Table 3). TR9 tended to retain a high proportion of lead at the cell wall,
Table 3

Subcellular distribution of lead in TR1 and TR9 phycobionts treated with $100 \mu \mathrm{M}$ $\mathrm{PbNO}_{3}$

\begin{tabular}{|c|c|c|c|c|c|c|}
\hline & \multicolumn{3}{|l|}{ TR1 } & \multicolumn{3}{|l|}{ TR9 } \\
\hline & Mean (\%) & $S D$ & $n$ & Mean (\%) & $S D$ & $n$ \\
\hline Cytosol-chloroplast & $8.61^{* * *}$ & 3.44 & 30 & 4.95 & 3.15 & 30 \\
\hline Vesicles & $11.11^{* * *}$ & 4.07 & 30 & 3.90 & 3.35 & 30 \\
\hline Cell wall & $0.50^{* * *}$ & 0.75 & 30 & 12.20 & 3.60 & 30 \\
\hline
\end{tabular}

Lead accumulation is expressed as a percentage of the osmium levels (reference element). For details, see materials and methods. ${ }^{* * *}$ indicates $P<0.0001$, i.e., the difference considered to be extremely statistically significant. Control cells (treated with $0 \mu \mathrm{M} \mathrm{PbNO}_{3}$ ) showed no detectable lead signal.

thus preventing its increased intracellular uptake. After $\mathrm{Pb}$ exposure, small electron-dense metal deposits were more frequently observed in the walls of TR9 cells than in the walls of TR1 cells (Fig. 1). Conversely, a higher accumulation and relatively large deposits of lead, forming small vesicles, were seen almost exclusively in TR1 (PbV in Fig. 1). In TR9, large intracellular deposits of Pb were conspicuously absent, especially in the electro-dense vesicles characteristic of these cells (Fig. 1 and Table 3 ).

\section{Antioxidant enzymes and HSP70 protein under prolonged $\mathrm{Pb}$ exposition}

In order to further characterize the defensive response of TR1 and TR9 microalgae, we studied the activities of several key antioxidant enzymes in response to increased levels of the HM. Accordingly, the effects of different $\mathrm{Pb}$ concentrations on the activity of GR, SOD, APx, and CAT were investigated in liquid cultures of isolated TR1 and TR9 phycobionts through spectrophotometric assays (for all enzymes) and zymograms (for GR and SOD). An induction of at least some of the antioxidant enzymes following the presumable increase in intracellular-Pb-induced ROS was expected, such that antioxidant induction should have been stronger in TR1 than in TR9, since the former accumulated significantly more $\mathrm{Pb}$. However, the results clearly indicated a completely different scenario. In general, it should be noted that initial (time $=0)$ and control $(\mathrm{Pb}=0)$ antioxidant activities were always higher in TR1 than in TR9 phycobionts, with a smaller difference for SOD (20\% higher in TR1 than in TR9) and a much larger one for GR (160\% higher in TR1 than in TR9, Fig. 2 inset). In addition, while CAT activity remained unchanged in both TR1 and TR9 even under $\mathrm{Pb}$ stress (Fig. 2D), the metal increased GR, SOD, and APx activities in TR9, but not in TR1, where APx activity was even depressed. Indeed, both the total activity determined in spectrophotometric assays (Fig. 2A) and the zymogram results (Fig. 3B) showed that in TR1 GR activity did not significantly change under Pb treatment, while in TR9 it was dramatically induced, reaching values similar to those of TR1 cells (ca. 48-51 nmol NADPH min ${ }^{-1} \mathrm{mg}^{-1}$ in $100 \mu \mathrm{M} \mathrm{Pb}$ ). As expected, the zymogram findings supported the total activity measurements of the spectrophotometric assays, since both phycobionts contain only one GR isoform (as determined by $1 \mathrm{D}-\mathrm{ND}$-PAGE). Similarly to the GR results, total SOD activity was not significantly modified by $\mathrm{Pb}$ exposure in TR1, while it increased by $>55 \%$ in TR9 cells treated with $100 \mu \mathrm{M} \mathrm{Pb}$ (Fig. 2B). SOD isoform analyses by ND-PAGE and activity staining distinguished two different patterns, with at least 6 discrete bands in TR1 and 7 in TR9. These bands were distributed in three main groups, corresponding to slow, intermediate, and high migration rates (Fig. 3A). In some cases, the lack of an effect of a certain treatment on total SOD activity, assayed spectrophotometrically in crude extracts, could probably be due to the redistribution of enzymatic activity among the different isoforms, such that the increase of some of them compensated for the decrease of others. 

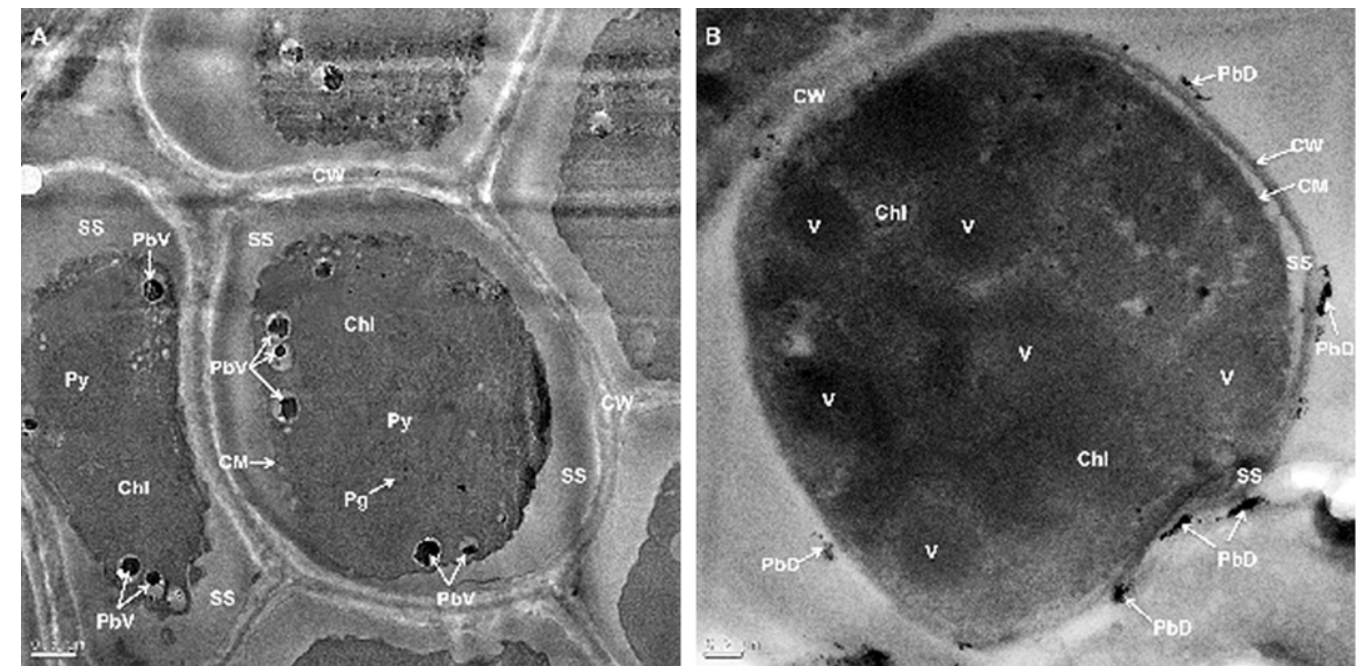

Fig. 1. Cellular distribution of lead ( $\mathrm{Pb}$ ) and the ultrastructure of Trebouxia TR1 (A) and $T$. TR9 (B) phycobionts treated with $100 \mu \mathrm{M} \mathrm{Pb}\left(\mathrm{NO}_{3}\right)_{2}$, as shown by TEM-coupled EDXS of ultrathin sections. Abbreviations: Chl, chloroplast; CM, cellular membrane; CW, cell wall; PbD, deposits of Pb; PbV, vesicles with deposits of Pb; Pg, pyrenoglobules; Py, pyrenoid; SS, secretion space; $\mathrm{V}$, vesicle. Bars: (A) $0.5 \mu \mathrm{m}$ and (B) $0.2 \mu \mathrm{m}$.

This was not the case for the effects of Pb on SOD activity in TR1, since activity staining of the SOD isoforms of treated cells did not significantly differ from that of control cells (Fig. 3A). Conversely, the relatively slight increase in total SOD activity induced by $\mathrm{Pb}$ in TR9 was almost exclusively accounted for by the intermediate bands, without any activity loss in the other bands (Fig. 3A). APx, a key enzyme in the removal of $\mathrm{H}_{2} \mathrm{O}_{2}$ generated by SOD and other cellular reactions, was modulated by $\mathrm{Pb}$ treatment, following opposite trends depending on phycobiont taxa (Fig. 2C). In TR1 cells, APx decreased significantly $(P<0.05)$ to ca. $20 \%$ and $30 \%$ of

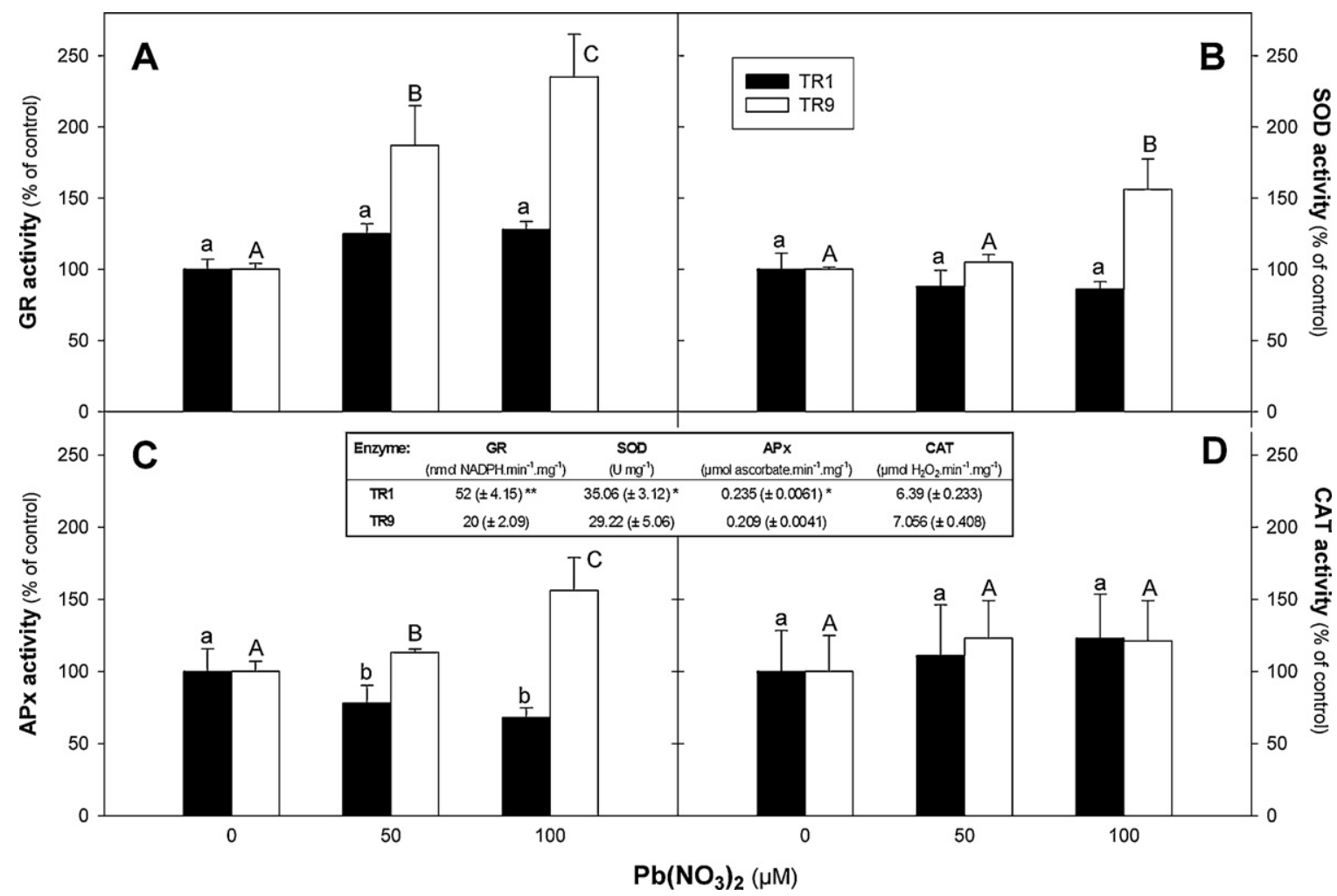

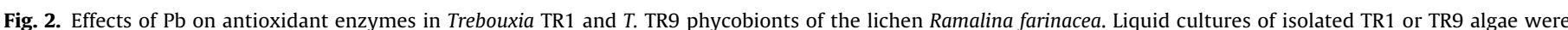

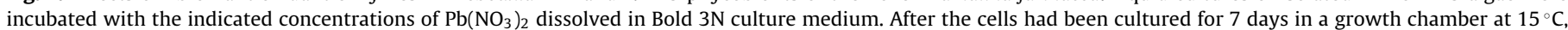

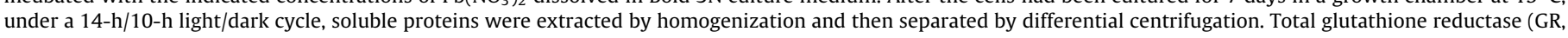

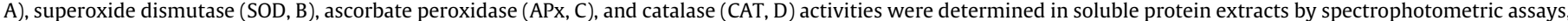

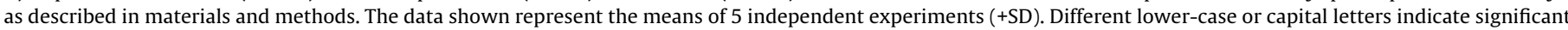

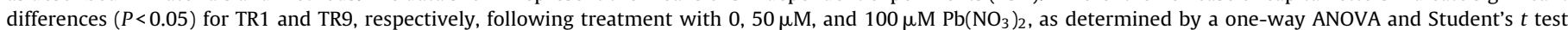

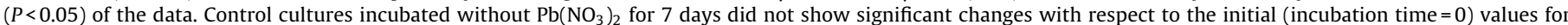

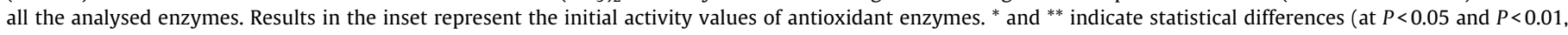
respectively) between TR1 and TR9, when subjected to a one-way ANOVA. 


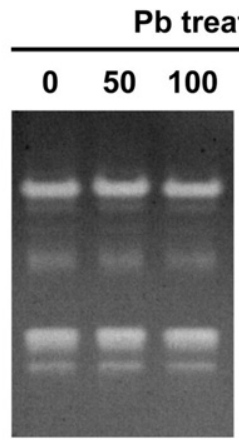

TR1

B
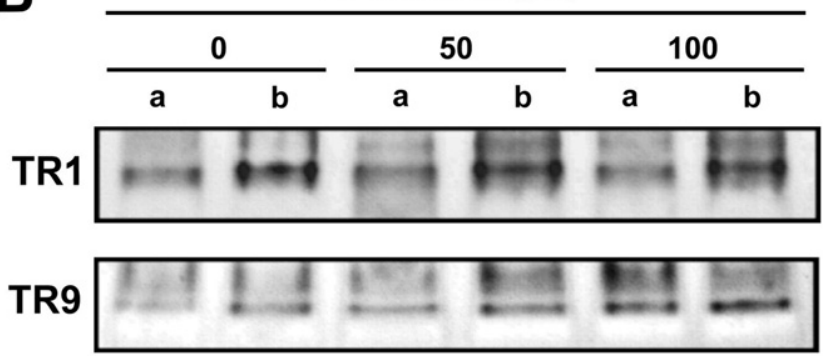

C

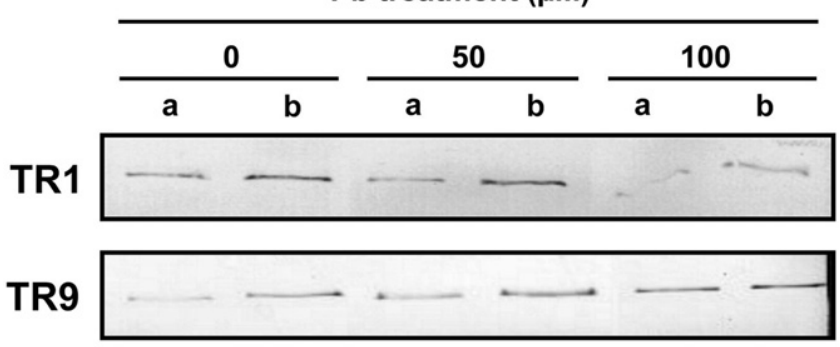

Fig. 3. Changes in superoxide dismutase (A), glutathione reductase isozymes (B), and in the HSP70 protein (C) in the lead-exposed Trebouxia TR1 and T. TR9 phycobionts of the lichen Ramalina farinacea. Liquid cultures of isolated TR1 or TR9 algae were incubated with the indicated concentrations of $\mathrm{Pb}\left(\mathrm{NO}_{3}\right)_{2}$ dissolved in Bold $3 \mathrm{~N}$ culture medium. After the cells had been cultured for 7 days in a growth chamber at $15^{\circ} \mathrm{C}$, under a 14 -h/10-h light/dark cycle, soluble proteins were extracted by homogenization and separated by differential centrifugation. Putative isozymes of SOD and GR were analyzed by ND-PAGE and activity staining, as described in materials and methods. In the case of GR, only one true GR band was observed (as judged by comparing activity staining in presence vs. absence of oxidized glutathione). The HSP70 protein was separated by SDS-PAGE and immunodetected by protein blotting of the soluble protein fraction employing commercially available anti-HsP70 polyclonal antibodies (AgriSera, Sweden). (a) and (b) indicate 10 or $20 \mu \mathrm{g}$ soluble protein of each extract loaded per lane, respectively.

the control value in response to 50 and $100 \mu \mathrm{M} \mathrm{Pb}$, respectively. However, in TR9 cells APx progressively increased with rising $\mathrm{Pb}$ concentrations, such that activity values very close to those of TR1 under the same conditions were reached (e.g., average AP values in $100 \mu \mathrm{M}$ Pb-treated cells were $0.201 \mu \mathrm{mol}$ ascorbate $\mathrm{min}^{-1} \mathrm{mg}^{-1}$ and $0.196 \mu \mathrm{mol}$ ascorbate $\mathrm{min}^{-1} \mathrm{mg}^{-1}$ for TR1 and TR9, respectively).

To estimate the effects of $\mathrm{Pb}$ on another important group of "stress-related proteins" involved in the repair mechanisms of damaged cellular components, we looked for changes in the steadystate level of HSP70 in HM-exposed TR1 and TR9 cells. As shown in Fig. 3C, the initial level of HSP70 was slightly lower in the latter. In accordance with the response of these same phycobionts to oxidative stress (del Hoyo et al., 2011), exposure to 50 and $100 \mu \mathrm{M} \mathrm{Pb}$ caused a strong increase in the amount of HSP70 in TR9, but there was either no significant change or a slight decrease, respectively, in TR1 cells.

\section{Effects of $\mathrm{Pb}$ on photosynthetic pigments and fluorescence parameters}

The possible impact on the physiological performance of the intracellular lead accumulation and the observed $\mathrm{Pb}$-dependent modulation of the antioxidant defences were studied by analyzing several key components of the photosynthetic apparatus and parameters of photosynthesis. Specifically, the concentrations of the photosynthetic pigments chlorophyll $a$, chlorophyll $b$, and carotenoid (Fig. 4) along with the de-epoxidation state of xanthophylls (DPS, Fig. 5D) and the fluorescence parameters $F_{\mathrm{v}} / F_{\mathrm{m}}, \Phi_{\mathrm{PSII}}$, and $q_{\mathrm{N}}$ (Fig. 5A-C) were measured in Pb-treated TR1 and TR9 cells over a period of 7 days. The results depicted in Fig. 4 clearly indicate that, in general, photosynthetic pigments were not strongly affected by the presence of intracellular $\mathrm{Pb}$ in either the TR1 or the TR9 phycobiont. Similar to oxidative stress (del Hoyo et al., 2011), $\mathrm{Pb}$ did not cause a decrease in chlorophyll $b$ content. In the presence of $\mathrm{Pb}$, chlorophyll $a$ and carotenoids were significantly $(P<0.05)$ diminished in TR1, while only the carotenoid content was affected in TR9. Nonetheless, pigment decay $>10 \%$ with respect to the control levels was not observed.

We further characterized the influence (or lack thereof) of intracellular $\mathrm{Pb}$ accumulation on the photosynthetic behaviour of TR1 and TR9 in terms of the response of key chlorophyll fluorescence parameters. Overall, photosynthetic electron transport was not affected by the presence of $\mathrm{Pb}$, as up to ca. 70 and $21 \mu \mathrm{g} \mathrm{Pb} / \mathrm{mg}$ (dry weight) was tolerated within TR1 and TR9 cells, respectively. Fig. 5A shows the effect of $\mathrm{Pb}$ on the maximum efficiency of PSII photochemistry after dark adaptation $\left(F_{\mathrm{v}} / F_{\mathrm{m}}\right)$. No significant differences were found between treated and control cells of both TR1 and TR9, reflecting the resistance of PSII to Pb treatments. PSII photochemical efficiency under actinic light similar to growing light ( $\Phi_{\text {PSII }}$, Fig. 5B) was also unchanged by Pb in both TR1 and TR9 phycobionts. The non-photochemical dissipation of absorbed light $\left(q_{\mathrm{N}}\right.$, Fig. 5C) was always lower in TR1. However, it was significantly $(P<0.05)$ decreased in Pb-treated TR9 cells, but relatively insensitive to the metal in TR1 cells. Interestingly, the levels of DPS were similar and constant for both phycobionts and both treatments.

\section{Discussion}

The results obtained in the present study clearly indicate that the ability of the lichen $R$. farinacea to moderately tolerate polluted environmental conditions in general, and $\mathrm{Pb}$ exposure in particular, can be explained, at least in part, by the tolerance of its two phycobionts, TR1 and TR9. However, each algal species seem to have developed a specific strategy, in which the integration of distinct ultrastructural, biochemical, and physiological features gives rise to the acquisition of similar levels of Pb tolerance. Support for this conclusion comes from the absence of any deleterious symptoms at the level of one of the main targets of lead toxicity, the chloroplast. Under the conditions of our experiments, i.e., a low irradiation of ca. $40 \mu \mathrm{mol}$ photon $\mathrm{m}^{-2} \mathrm{~s}^{-1}$ as actinic light, Pb caused little alteration of the phycobionts' pigment content (Fig. 4 ) and $F_{\mathrm{v}} / F_{\mathrm{m}}$ values (Fig. 5), thus confirming that only direct $\mathrm{Pb}$ effects were registered, rather than effects produced by the addition of light stress to $\mathrm{Pb}$ treatment. As our results failed to show a correlation between DPS and $q_{\mathrm{N}}$ values in these chlorobionts, it is likely that alternative mechanisms to the xanthophyll cycle are responsible for the 


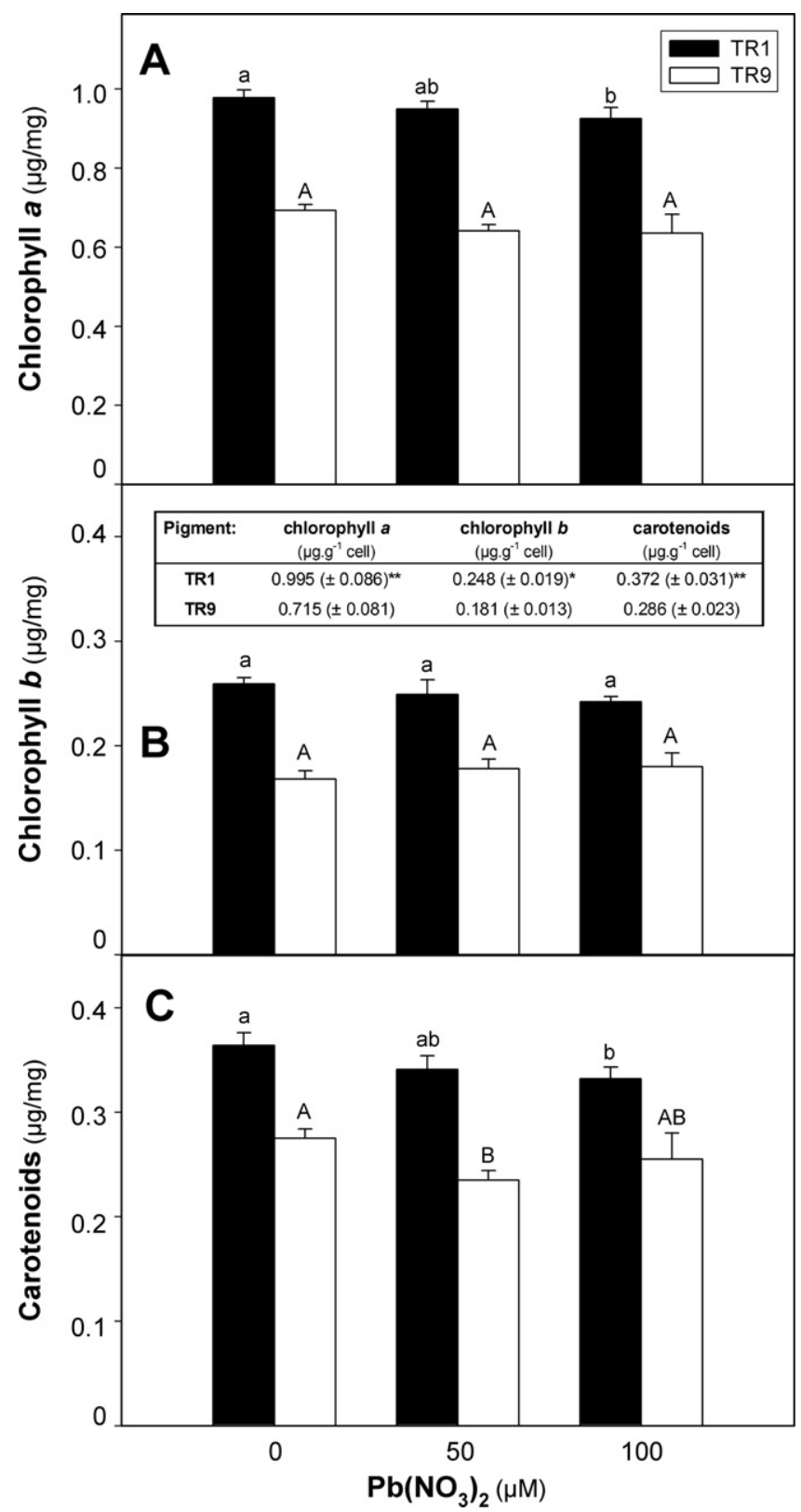

Fig. 4. Chlorophyll $a$, chlorophyll $b$, and carotenoids in Trebouxia TR1 and T. TR9 phycobionts of the lichen Ramalina farinacea exposed to $\mathrm{Pb}$. Liquid cultures of isolated TR1 or TR9 algae were incubated with the indicated concentrations of $\mathrm{Pb}\left(\mathrm{NO}_{3}\right)_{2}$ dissolved in Bold $3 \mathrm{~N}$ culture medium. After the cells had been cultured for 7 days in a growth chamber at $15^{\circ} \mathrm{C}$, under a 14 -h/10-h light/dark cycle, chlorophylls and carotenoids were determined spectrophotometrically as described in materials and methods. Depicted values represent mean results $( \pm S D)$ from 9 independent experiments. Different lower-case or capital letters indicate significant differences $(P<0.05)$ among $0,50 \mu \mathrm{M}$, and $100 \mu \mathrm{M} \mathrm{Pb}\left(\mathrm{NO}_{3}\right)_{2}$ treatment for TR1 and TR9, respectively, when the data were subjected to a one-way ANOVA and Student's $t$ test $(P<0.05)$. Results in the inset represent the initial (incubation time $=0$ ) values of photosynthetic pigments. ${ }^{*}$ and ${ }^{* *}$ indicate statistical differences (at $P<0.05$ and $P<0.01$, respectively) between TR1 and TR9, when subjected to a one-way ANOVA.

dissipation of light energy in one or both Trebouxia phycobionts, as proposed for Asterochloris erici (Ahmadjian) Skaloud \& Peksa by Gasulla et al. (2009). Interestingly, the Pb-related decline of $q_{\mathrm{N}}$ in TR9 was not trivial (Fig. 5), indicating that some mechanisms in TR9 are $\mathrm{Pb}$ sensitive and different than those present in TR1. In addition, $q_{\mathrm{N}}$ was higher in TR9 than in TR1 cells, even at $100 \mu \mathrm{M} \mathrm{Pb}$.

Sanità di Toppi et al. (2008) dissected the physiological response of cultured Trebouxia impressa phycobionts to relatively prolonged Cd exposure into temporally distinguished "first line" and "second line" detoxification mechanisms. "First line" mechanisms include extracellular cell-wall HM immobilization, vacuolar compartmentalization, and the synthesis of glutathione and phytochelatins. "Second line" mechanisms, activated when HM detoxification by "first line" mechanisms is overwhelmed, involve the induction of "stress proteins" and antioxidant enzymes. Soluble antioxidants, such as glutathione and ascorbate, and antioxidant enzymes, such as SODs, GR, CAT, and peroxidases, are involved during the entire process of HM detoxification, since they participate in HMchelation ("first line") and antioxidant protection ("second line"). Our experiments were based on a relatively prolonged exposure of the phycobionts to $\mathrm{Pb}$ (7 days), with all of the analyses performed at the end of the treatments, hence we could not temporally dissect "first line" from "second line" detoxification mechanisms. However, the markedly different distribution of extra- and intracellular levels of $\mathrm{Pb}$ between TR1 and TR9 strongly indicates that in the latter HM is prevented from entering the cell interior by binding to exchange sites in the cell wall in much greater amounts than is the case in TR1 (Fig. 1, and Tables 2 and 3). This observation is supported by the ultrastructural differences between TR1 and TR9 cell walls. In TR1 algae, the cell wall is made up of four TEM-distinguishable layers, which account for a total thickness of ca. $150 \mathrm{~nm}$ (in axenic culture), while in TR9 the cell wall is nearly three times thicker (ca. $410 \mathrm{~nm}$, in culture), and consists of only three well-differentiated layers (Casano et al., 2011). In other studies, cell-wall thickening was commonly observed in vascular plants and mosses exposed to HMs (Krzeslowska et al., 2009; Bouazizi et al., 2010; Yu et al., 2011). This response was associated with increased amounts of polysaccharides in the cell walls (Wierzbicka, 1998). In both symbiotic and free-living algae, the retention of HMs at the cell wall is considered to be one of the main "first line" protective mechanisms, since it excludes an important fraction of the toxic element from the protoplast (Sanità di Toppi et al., 2008; Andrade et al., 2010 and references therein). This may well have been the case for the TR9 phycobiont, while TR1 tended to immobilize $\mathrm{Pb}$ as significant deposits in small intracellular vesicles (Fig. 1 and Table 3). Vacuolar/vesicular compartmentalization of HMs has been frequently observed in plant tissues and is considered to be another "first line" mechanism of detoxification since it restricts the phytotoxicity of metals by isolating them from the cytoplasm/chloroplast (Hall, 2002; Liu and Kottke, 2004a,b; Jin et al., 2008; Daud et al., 2009; Jabeen et al., 2009).

However, an undetermined proportion of intracellular soluble and bioactive $\mathrm{Pb}$ also seemed to be present in both phycobionts, and especially within TR9 cells, in which significant deposits of insoluble metal were not observed (Fig. 1). This result suggests an important role for a third type of "first line" defence mechanism: the complexation/immobilization of HMs with organic compounds such as thiol peptides. It is well established that in response to HM stress photobionts (but not mycobionts) are able to rapidly increase the production of a class of thiol peptides called phytochelatins (Sanità di Toppi et al., 2008; Pawlik-Skowronska and Bačkor, 2011 and references therein). Phytochelatins form binary complexes with $\mathrm{Cd}, \mathrm{Pb}$, and $\mathrm{Zn}$ that can then be transported and accumulated intracellularly, bypassing the toxic effects of these HMs (Pal and Rai, 2010). Determinations of non-protein thiols, as well as their main substrate, reduced glutathione, was beyond the scope of the present investigation; but it is known that the enzyme GR plays a critical role in the redox balance of glutathione and hence in the availability of substrate for phytochelatin synthesis. Our results strongly support the differential modulation of this antioxidant enzyme by $\mathrm{Pb}$ in TR1 and TR9 (Figs. 2 and 3); that is, while GR remained unchanged in TR1, it was highly induced by $\mathrm{Pb}$ treatments in TR9 compared to the respective controls. Moreover, control-level expression of GR was significantly higher in TR1 than in TR9. Interestingly, the final effect of this differential GR 


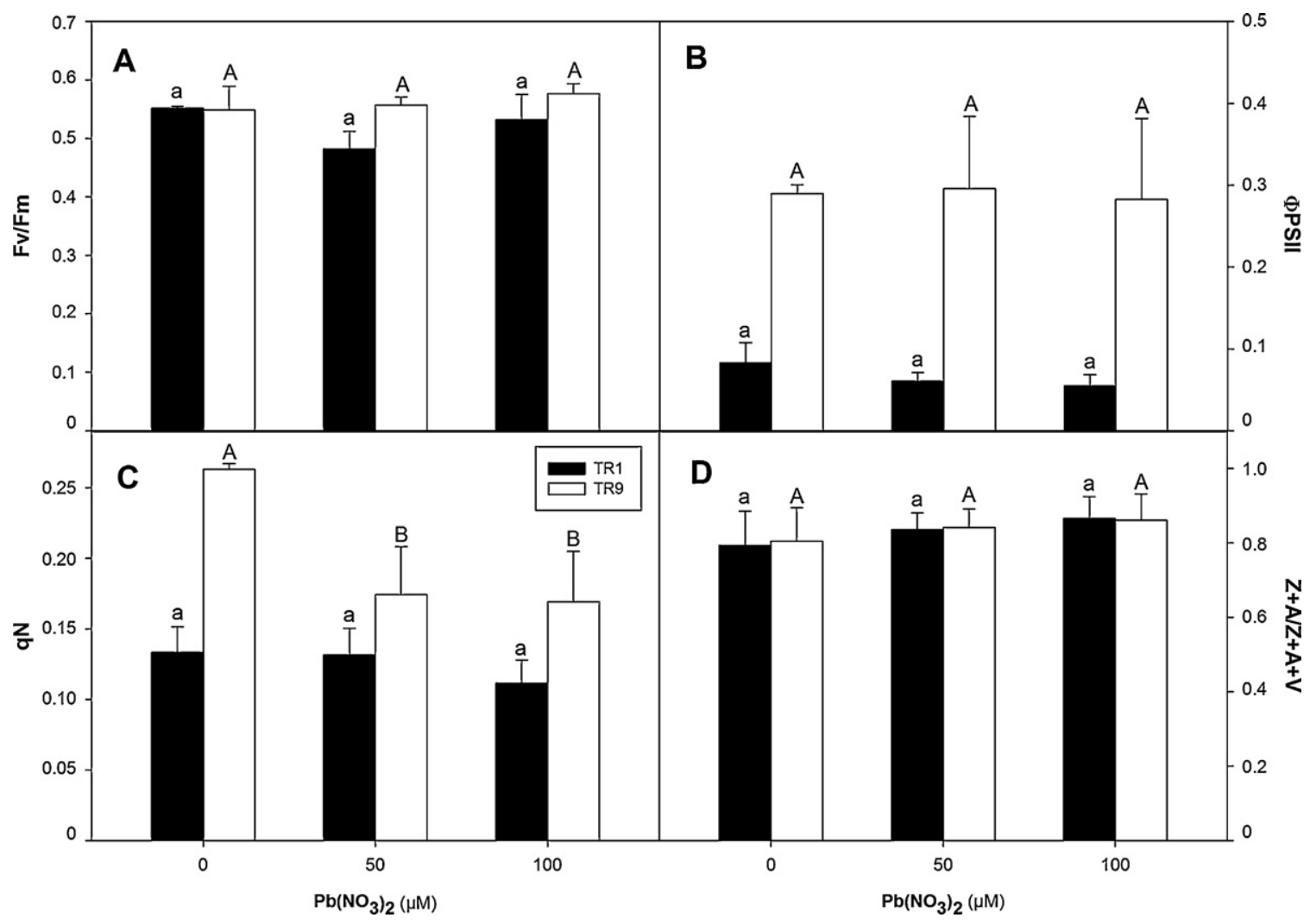

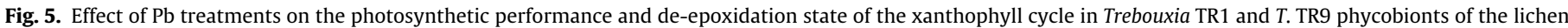

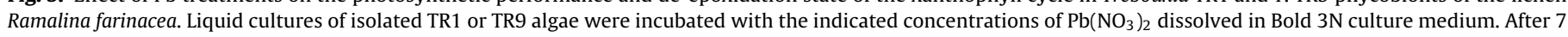

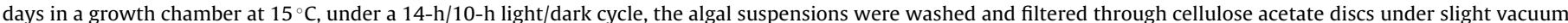

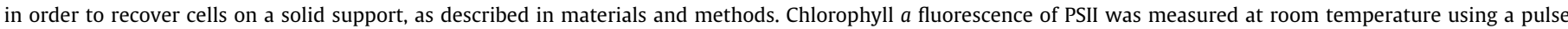

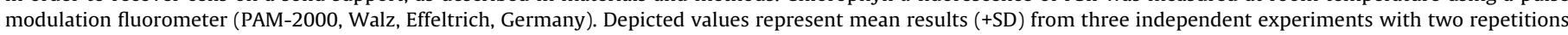

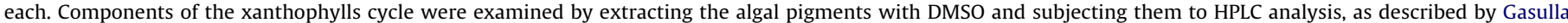

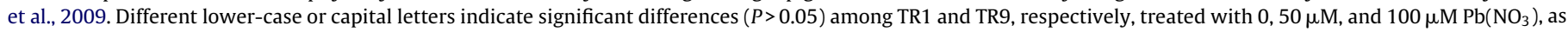
determined by a one-way ANOVA and Student's $t$ test of the data $(P>0.05)$.

regulation rendered very similar final results, as the differences in the activities of this enzyme in TR1 and TR9 cells treated with $100 \mu \mathrm{M} \mathrm{Pb}$ were not significant. Therefore, it is possible to speculate that at least the reduction state of the glutathione pool and possibly also substrate availability for phytochelatin synthesis may be comparable in TR1 and TR9 microalgae.

As stated in detail in the Introduction, some of the main toxic effects of $\mathrm{Pb}$ are derived from its capacity to stimulate ROS production (Sharma and Dietz, 2008), while others depend on interaction of the metal with the $-\mathrm{SH}$ groups of essential macromolecules (Liu et al., 2009). Accordingly, antioxidant enzymes such as GR, SOD, APX, and CAT, as well as repair proteins with chaperone functions are the main components of "second line" defence mechanisms against $\mathrm{Pb}$. SODs convert superoxide anion radicals into hydrogen peroxide, which in plants and algae is then reduced to water through the combined actions of the ascorbate-glutathione cycle (Mittler et al., 2004), CAT, and peroxidases. In our study, the results obtained for SOD and APx enzymes in TR1 and TR9 algae exposed to $\mathrm{Pb}$ were similar to those obtained for GR (Figs. 2 and 3). Thus, compared to the respective controls, while in TR1 cells SOD was not significantly modified and APx was diminished in the presence of $\mathrm{Pb}$, in TR9 cells the levels of both enzymes were significantly higher. As in GR, the control values of SOD and APx were higher in TR1 than in TR9, but the activities of each enzyme in the presence of $100 \mu \mathrm{M}$ $\mathrm{Pb}$ were very similar in the two species. Also noteworthy was the parallel increase of SOD and APx in TR9 cells treated with $100 \mu \mathrm{M} \mathrm{Pb}$ (Fig. 3); both enzymes were stimulated by approximately $55 \%$ over control values, indicating a coordinated activation of the various components of the cellular antioxidant system in order to prevent oxidative damage.

HSP70, one of the most well-studied chaperone proteins, has been implicated in the physiological response to HM in lichen algae (Bačkor et al., 2006). We found that $\mathrm{Pb}$ exposure caused important changes in the steady-state levels of HSP70 in isolated $R$. farinacea phycobionts. Similar to the findings for the antioxidant enzymes, the initial levels of HSP70 were slightly lower in TR9 than in TR1. However, in TR9 exposed to increasing amounts of $\mathrm{Pb}$, the levels of the protein increased. This was in contrast to TR1 cells, in which the initially high levels of the chaperone were not maintained in response to high $\mathrm{Pb}$ exposure (Fig. $3 \mathrm{C}$ ).

In general, our results accord with recent findings regarding the effects of oxidative stress on $R$. farinacea phycobionts (del Hoyo et al., 2011). That comparative analysis of TR1 and TR9 responses to oxidative treatments suggested a higher capacity of the latter phycobiont to increase both antioxidant protection and repair mechanisms. However, even though the defence mechanisms of TR1 are apparently not induced under oxidative and other types of environmental stress, such as $\mathrm{Pb}$ exposure, this lichenic alga does not seem to remain completely "unprotected," since its relatively high basal level of defence responses are maintained under stress. We speculate that TR1 and TR9 algae represent two different biological strategies against stress: TR1 seems to be relatively poorly "protected" from the external environment due to its thinner and qualitatively different cell wall (compared to that of TR9); hence it is obligated to invest a relatively large amount of metabolic energy in order to maintain its intracellular defence and repair 
mechanisms at a high level of activity. By contrast, TR9 seems to be relatively better "isolated" from the external medium by a thicker cell wall; at the same time, the non-photochemical dissipation of excess energy $\left(q_{\mathrm{N}}\right)$, which prevents ROS formation, is more active in this phycobiont (Fig. 3 and del Hoyo et al., 2011). Consequently, it may be that under "normal" conditions, the intracellular defence mechanisms of TR9 operate at minimum levels. This low metabolic investment in defence would allow TR9 algae to sustain high rates of photosynthesis (as evidenced by higher $\Phi_{\text {PSII }}$ values) and biomass accumulation under relatively high irradiances and temperatures (Casano et al., 2011). When external conditions surpass certain thresholds and extracellular barriers are no longer effective, the intracellular defence mechanisms of TR9 phycobionts can be rapidly induced.

In previous studies, $R$. farinacea was proposed as a good example of symbiotic adaptation, in which habitat alterations can flexibly be addressed by modifying the number or proportion of coexisting TR1 and TR9 phycobionts (del Campo et al., 2010; Casano et al., 2011). Recent studies from our laboratory have revealed the presence of TR1 with other Trebouxia phycobionts in other lichen species, suggesting that the coexistence of two or perhaps more physiologically different Trebouxia microalgae within the same thallus is more common than previously thought (del Campo et al., 2012, unpubl. res.). The results presented herein provide insight - while posing new questions - into the ultrastructural and physiological basis of two different strategies to cope with $\mathrm{HMs}(\mathrm{Pb})$, and probably other types of environmental stress. Since these strategies evolved in two symbiotic microalgae that share the same microhabitat, it is possible that $R$. farinacea and other lichenized fungi utilize two or even more functionally distinct phycobionts, both to improve their ability to adapt to variations in ecological conditions and to colonize new ecological niches.

\section{Acknowledgements}

This study was supported by the Spanish Ministry of Science and Innovation (CGL2009-13429-C02-01/02) and the Generalitat Valenciana (PROMETEO 174/2008 and GVACOMP2011-205). We are grateful to the Central Support Service in Experimental Research (SCSIE), University of Valencia (Spain), for the TEM studies. We acknowledge Dr. Said Agouram (SCSIE, University of Valencia, Spain) for TEM-EDXS characterizations and for helpful discussions during the TEM investigations. We thank Wendy Ran and Daniel Sheerin for the English revision of the manuscript.

\section{References}

Aebi H. Catalase in vitro. Method Enzymol 1984;105:121-6.

Ahmadjian V. The lichen symbiosis. New York: John Willey \& Sons, Inc; 1993.

Amako K, Chen GX, Asada K. Separate assays specific for ascorbate peroxidase and guaiacol peroxidase and for the chloroplastic and cytosolic isozymes of ascorbate peroxidase in plants. Plant Cell Physiol 1994;35:497-504.

Andrade LR, Leal RN, Noseda M, Duarte MER, Pereira MS, Mourão PAS, et al. Brown algae overproduce cell wall polysaccharides as a protection mechanism against the heavy metal toxicity. Mar Pollut Bull 2010;60:1482-8.

Arhoun M, Barreno E, Torres JR, Ramis-Ramos G. Releasing rates of inorganic ions from the lichen Ramalina farinacea by capillary zone electrophoresis (CZE) as an indicator of atmospheric pollution. Crypt Bryol Lichenol 2000;21:275-89.

Bačkor M, Vaczi P. Copper tolerance in the lichen photobiont Trebouxia erici (Chlorophyta). Environ Exp Bot 2002;48:11-20.

Bačkor M, Gibalová A, Budová J, Mikeš J, Solár P. Cadmium-induced stimulation of stress-protein hsp70 in lichen photobiont Trebouxia erici. Plant Growth Regul 2006;50:159-64.

Bačkor M, Pawlik-Skowrońska B, Budová J, Skowronski T. Response to copper and cadmium stress in wild-type and copper tolerant strains of the lichen alga Trebouxia erici: metal accumulation, toxicity and non-protein thiols. Plant Growth Regul 2007;52:17-27.

Bačkor M, Loppi S. Interactions of lichens with heavy metals. Biol Plant 2009;53:214-22.

Barreno, E. "Expression of Interest» FP6 2002-2006, UE. MOEBIOS. “Monitoring the effects of global environmental change on the biodiversity of sensitive organisms". Towards a network of excellence for Europe of biomonitoring global environmental change. TP 1.6. Sustainable development, global change and ecosystems. http://eoi.cordis.lu/search_form.cfm; 2002.

Beck A. Photobiont inventory of a lichen community growing on heavy-metal-rich rock. Lichenologist 1999;31:501-10.

Bilger W, Björkman O. Temperature dependence of violaxanthin deepoxidation and non-photochemical fluorescence quenching in intact leaves of Gossypium hirsutum L. and Malva parviflora L. Planta 1991;184:226-34.

Bold HC, Parker BC. Some supplementary attributes in the classification of Chlorococcum species. Arch Microbiol 1962;42:267-88.

Bouazizi H, Jouil H, Geitmann A. ElFerjani E. Structural changes of cell wall and lignifying enzymes modulations in bean roots in response to copper stress. Biol Trace Elem Res 2010;136:232-40.

Branquinho C, Brown DH. A method for studying the cellular location of lead in lichens. Lichenologist 1994;26:83-90.

Branquinho C, Brown DH, Maguas C, Catarino F. Lead (Pb) uptake and its effects on membrane integrity and chlorophyll fluorescence in different lichen species. Environ Exp Bot 1997;37:95-105.

Branquinho C. Lichens. In: Prasad MNV, editor. Metals in the environment: analysis by biodiversity. New York: Marcel Dekker; 2001. p. 117-57.

Brown DH, Beckett RP. Minerals and lichens: acquisition, localization and effect. In: Vicente C, Brown DH, Legaz ME, editors. Surface physiology of lichens. Madrid: Universidad Complutense de Madrid; 1985. p. 127-49.

Calatayud A, Deltoro VI, Abadía A, Abadía J, Barreno E. Effects of ascorbate feeding on chlorophyll fluorescence and xanthophylls cycle components in the lichen Parmelia quercina exposed to atmospheric pollutants. Physiol Plant 1999; 105:679-84.

Casano LM, del Campo EM, García-Breijo FJ, Reig-Armiñana J, Gasulla F, del Hoyo A, et al. Two Trebouxia algae with different physiological performances are ever-present in lichen thalli of Ramalina farinacea. Coexistence vs. competition? Environ Microbiol 2011;13:806-18.

Daud MK, Sun YQ Dawood M, Hayat Y, Variath MT, Wu YX, et al. Cadmium-induced functional and ultrastructural alterations in roots of two transgenic cotton cultivars. J Hazard Mater 2009;161:463-73.

del Campo EM, Gimeno J, Casano LM, Gasulla F, García-Breijo F, Reig-Armiñana J, et al. South European populations of Ramalina farinacea (L.) Ach. share different Trebouxia algae. Bibl Lichenol 2010;105:247-56.

del Hoyo A, Álvarez R, del Campo EM, Gasulla F, Barreno E, Casano LM. Oxidative stress induces distinct physiological responses in the two Trebouxia phycobionts of the lichen Ramalina farinacea. Ann Bot 2011;107:109-18.

De Vera JP, Rettberg P, Ott S. Life at the limits: capacities of isolated and cultured lichen symbionts to resist extreme environmental stresses. Origins Life Evol Biosph 2008;38:457-68.

Epstein AL, Gussman CD, Blaylock MJ, Yermiyahu U, Huang JW, Kapulnik Y, et al. EDTA and Pb-EDTA accumulation in Brassica juncea grown in Pb-amended soil. Plant Soil 1999;208:87-94.

Fadila K, Houria D, Rachid R, Reda DM. Cellular response of a pollution bioindicator model (Ramalina farinacea) following treatment with fertilizer(NPKs). Am-Euras J Toxicol Sci 2009;1:69-73.

Garty J. Biomonitoring atmospheric heavy metals with lichens: theory and application. Crit Rev Plant Sci 2001;20:309-71.

Gasulla F, de Nova PG, Esteban-Carrasco A, Zapata JM, Barreno E, Guéra A. Dehydration rate and time of desiccation affect recovery of the lichen alga Trebouxia erici: alternative and classical protective mechanisms. Planta 2009;231:195-208.

Gasulla F, Guéra A, Barreno E. A simple micromethod for isolating lichen photobionts. Symbiosis 2010;51:175-9.

Genty B, Briantais JM, Baker NR. The relationship between the quantum yield of photosynthetic electron transport and quenching of chlorophyll fluorescence. Biochim Biophys Acta 1989;990:87-92.

Grube M. Die hard: lichens. In: Seckbach J, Grube M, editors. Symbioses and stress: joint ventures in biology. Hidelberg: Springer; 2010. p. 209-23.

Hall JL. Cellular mechanisms for heavy metal detoxification and tolerance. J Exp Bot 2002;53:1-11.

Hauck M, Helms G, Friedl T. Photobiont selectivity in the epiphytic lichens Hypogymnia physodes and Lecanora conizaeoides. Lichenologist 2007;39:195-204.

Jabeen R, Ahmad A, Iqbal M. Phytoremediation of heavy metals: physiological and molecular mechanisms. Bot Ver 2009;75:339-64.

Jin XF, Yang XE, Islam E, Liu D, Mahmood Q Li H, Li JY. Ultrastructural changes, zinc hyperaccumulation and its relation with antioxidants in two ecotypes of Sedum alfredii Hance. Plant Physiol Biochem 2008;46:997-1006.

Krzeslowska M, Lenartowska M, Mellerowicz EJ, Samardakiewicz S, Wozny A. Pectinous cell wall thickenings formation - a response of moss protonemata cells to lead. Environ Exp Bot 2009;65:119-31.

Liu DH, Kottke I. Subcellular localization of copper in the root cells of Allium sativum by electron energy loss spectroscopy (EELS). Bioresour Technol 2004a;94: 153-8.

Liu DH, Kottke I. Subcellular localization of cadmium in the root cells of Allium cepa by electron energy loss spectroscopy and cytochemistry. J Biosci 2004b;29: 329-35.

Liu D, Li T-Q, Jin X-F, Yang X-E, Islam E, Mahmood Q. Lead induced changes in the growth and antioxidant metabolism of the lead accumulating and nonaccumulating ecotypes of Sedum alfredii. J Int Plant Biol 2008;50:129-40.

Liu T, Liu S, Guan H, Ma L, Chen Z, Gu H, et al. Transcriptional profiling of Arabidopsis seedlings in response to heavy metal lead (Pb). Environ Exp Bot 2009;67:377-86.

Loppi S, Frati L. Lichen diversity and lichen transplants as monitors of air pollution in a rural area of central Italy. Environ Monit Assess 2006;114:361-75. 
Margulis L, Barreno E. Looking at lichens. Bioscience 2003;53:776-8.

Mittler R, Vanderauwera S, Gollery M, Van Breusegem F. Reactive oxygen gene network of plants. Trends Plant Sci 2004;9:490-8.

Nimis PL, Scheidegger C, Wolseley P. Monitoring with lichens - monitoring lichens. Dordrecht: Kluwer; 2002.

Pal R, Rai JP. Phytochelatins: peptides involved in heavy metal detoxification. Appl Biochem Biotechnol 2010;160:945-63.

Pawlik-Skowronska B, Bačkor M. Zn/Pb-tolerant lichens with higher content of secondary metabolites produce less phytochelatins than specimens living in unpolluted habitats. Environ Exp Bot 2011;72:64-70.

Phang IC, Leung DW, Taylor HH, Burritt DJ. The protective effect of sodium nitroprusside (SNP) treatment on Arabidopsis thaliana seedlings exposed to toxic level of $\mathrm{Pb}$ is not linked to avoidance of $\mathrm{Pb}$ uptake. Ecotoxicol Environ Saf 2011:74:1310-5.

Pinto E, Sigaud-kutner TCS, Leitão MAS, Okamoto OK, Morse D, Colepicolo P. Heavy metal-induced oxidative stress in algae. J Phycol 2003;39:100818.

Riga-Karandinos AN, Karandinos MG. Assessment of air pollution from a lignite power plant in the plain of Megalopolis (Greece) using as biomonitors three species of lichens; impacts on some biochemical parameters of lichens. Sci Total Environ 1998:215:167-83.
Sanità di Toppi L, Pawlik-Skowronska B, Vurro E, Vattuone Z, Kalinowska R, Restivo FM, et al. First and second line mechanisms of cadmium detoxification in the lichen photobiont Trebouxia impressa (Chlorophyta). Environ Pollut 2008;151:280-6.

Sharma P, Dubey RS. Lead toxicity in plants. Braz J Plant Physiol 2005;17:35-52.

Sharma SS, Dietz K-J. The relationship between metal toxicity and cellular redox imbalance. Trends Plant Sci 2008;14:43-50.

Słomka A, Libik-Konieczny M, Kuta E, Miszalski Z. Metalliferous and nonmetalliferous populations of Viola tricolor represent similar mode of antioxidative response. J Plant Physiol 2008;165:1610-9.

Verma S, Dubey RS. Lead toxicity induces lipid peroxidation and alters the activities of antioxidant enzymes in growing rice plants. Plant Sci 2003;164: 645-55.

Wellburn AR. The spectral determination of chlorophylls a and b, as well as tota carotenoids, using various solvents with spectrophotometers of different resolution. J Plant Physiol 1994;144:307-13.

Wierzbicka M. Lead in the apoplast of Allium cepa L. root tips - ultrastructural studies. Plant Sci 1998;133:105-19.

Yu HN, Liu P, Wang ZY, Chen WR, Xu GD. The effect of aluminum treatments on the root growth and cell ultrastructure of two soybean genotypes. Crop Protec $2011 ; 30: 323-8$ 